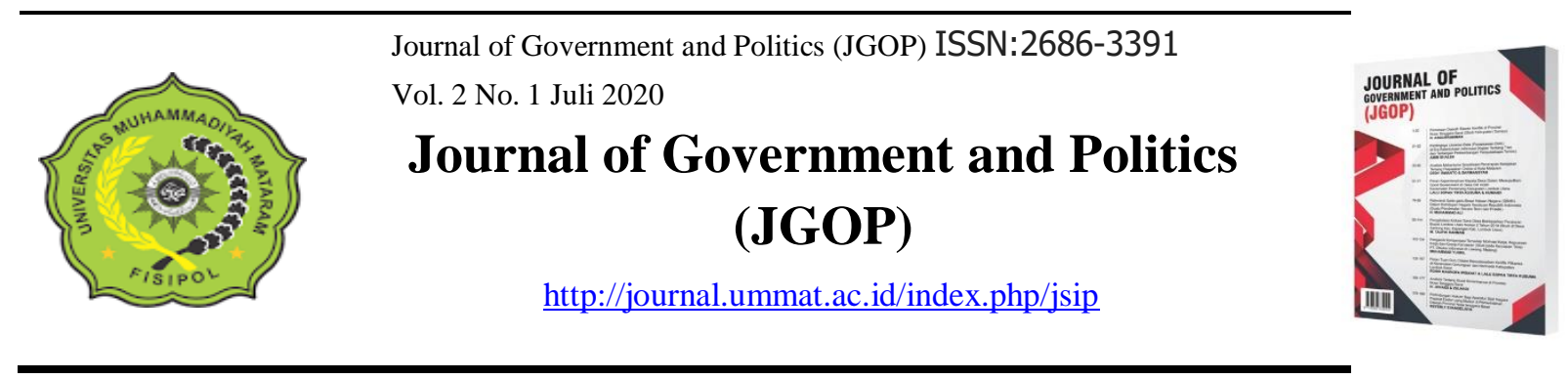

\title{
KONFLIK KEPENTINGAN PASCA RECALL DALAM PERSPEKTIF KELEMBAGAAN PARTAI POLITIK
}

Rahmat $^{1}$, Ayatullah Hadi ${ }^{2}$, Darmansyah ${ }^{3}$

1,2,3 Universitas Muhammadiyah Mataram

InfoArtikel

Sejarah Artikel:

Diterima: 06-05-2020

Disetujui: 09-07-2020

Dipublikasikan :21-072020

Kata Kunci :

Recall,Partai Hanura,

Kelembagaan

\section{Abstrak}

Proses recall terhadap saudara Arif Usman mengakibatkan lambannya berbagai proses kebijakan di internal partai. kebijakan pasca Recall Arif Usman menyebabkan konflik internal secara kelembagaan di tubuh Partai Hanura Lombok Utara. Analisis data dengan menggunakan tehnik Miles dan Huberman, yaitu, mulai pengumpulan data dilapangan, reduksi data, penyajian data sampai pada penarikan kesimpulan. Recall dipahami secara umum sebagai penarikan kembali anggota DPRD untuk diberhentikan dan digantikan dengan anggota yang lain sebelum berakhir masa jabatan anggota DPRD yang ditarik tersebut. Penelitian ini bertujuan untuk mendapat gambaran tentang konflik inetrnal yang terjadi di tubuh Partai Hanura Lombok Utara pasca terjadinya Recall oleh satu anggota Anggota DPRD Lombok Utara dari Partai Hanura. Metode penelitian yag digunakan dalam penelitian ini menggunakan pendekatan kualitatif, dengan tehnik pengumpulan data berupa wawancara, dokumntasi dan tinajuan pustaka. Hasil penelitian menunjukan dalam kasus Recall yang dilakukan oleh Dewan Pimpinan Cabang (DPC) Partai Hanura Kabupaten Lombok Utara (KLU) terhadap Arif Usman, salah satua anggota atau kader partai Hanura yang duduk sebagai anggota DPRD Kab. Lombok Utara priode 2014-2019. Karena dipicu oleh berbagai gejolak internal partai, adanya perbedaan pandangan antara anggota yang bersangkutan dengan pengurus partai. Adapun dasar serta landasan mekanisme recall yang dilakukan oleh DPC Partai Hanura Kabupaten Lombok Utara adalah berdasarkan aturan perundangan-undangan serta berdasarkan ketentuan dalam AD/ART Partai Hanura sendiri. Terdapat dua hal penting yang menjad iimplikasi dari adanya recall terhadap anggota yang dilakukan oleh partai Hanura Kabupaten Lombok Utara, pertama terjadinya konflik internal kelembagaan partai yang berkepanjangan terkait dengan penetuan penggati dari pihak yang direcall, kedua, adalah terganggunya jalannya kebijakan di internal DPRD Kabupaten Lombok Utara. Oleh karena itu langkah yang dilakukan oleh DPC Partai Hanura Kabuapten Lombok Utara adalah memperbanyak upaya musyarawah untuk konsolidasikan kelembagaan partai serta memperkuat hubungan dengan aktor luar seperti partaipartai lain rekan dalam satu fraksi di DPRD Kabupaten Lombok Utara . 


\title{
CONFLICTS OF POST RECALL INTEREST IN THE POLITICAL PARTY INSTITUTION PERSPECTIVE
}

\begin{abstract}
The recall process of Arif Usman's brothers resulted in slow processes of various internal party policies. Arif Usman's recall policies caused internal institutional conflict within the North Lombok Hanura Party. Data analysis using the technique of Miles and Huberman, that is, starting from data collection in the field, data reduction, data presentation until drawing conclusions. Recall is generally understood as the withdrawal of DPR members to be dismissed and replaced by other members before the term of office of the withdrawn DPR member expires. This study aims to get a picture of the internal conflict that occurred within the North Lombok Hanura Party after the Recall was made by a member of the North Lombok DPRD from the Hanura Party. The research method used in this study used a qualitative approach, with data collection techniques in the form of interviews, documentations and library progress. The results showed in the Recall case conducted by the Branch Leadership Council (DPC) of the North Lombok Regency (KLU) against Arif Usman, one of the members or cadres of the Hanura party who sat as a member of the District Parliament. North Lombok period 2014-2019. Because it was triggered by various internal party upheavals, there were differences of opinion between the members concerned and the party management. The basis and basis of the recall mechanism carried out by the DPC of the North Lombok Regency Hanura Party is based on the laws and regulations and based on the provisions in the AD / ART of the Hanura Party itself. There are two important things that become the implication of the recall of members carried out by the North Lombok Regency Hanura party, firstly a prolonged internal institutional conflict related to the determination of the replacement of the recalled party, secondly, is the disruption of the policy in the North Lombok Regency DPRD . Therefore, the steps taken by the DPC of the North Lombok Regency of the Hanura Party were to expand the musyarawah efforts to consolidate party institutions and strengthen relations with external actors such as other parties in a faction in the North Lombok Regency DPRD.
\end{abstract}

\footnotetext{
*Alamat Korespondensi:

${ }^{1}$ Rahmat@gmail.com

2 hadi.ayatullah@yahoo.co.id

${ }^{3}$ Darmansyah.ai59@yahoo.co.id
} 


\section{PENDAHULUAN}

Negara Kesatuan Republik Indonesia merupakan negara hukum yang berdasarkan Pancasila dan Undang-Undang Dasar 1945, yang bertujuan untuk mewujudkan tata kehidupan berbangsa dan bernegara yang tertib, makmur dan berkeadilan. Undang-Undang Dasar 1945 sebagai konstitusi negara republik Indonesia mengalami perjalanan yang cukup panjang dalam perjuangan bangsa Indonesia, baik dalam kedudukannya sebagai konstitusi, maupun dalam pelaksaan penyelenggaraan kehidupan berbangsa dan bernegara. Negara Republik Indonesia merupakan sebuah negara kesatuan yang berbentuk republik, dan menjalankan pemerintahan dalam bentuk demokrasi ${ }^{1}$.

Demokrasi secara terminologi berasal dari bahasa Yunani demokratia, yang diambil dari kata demos dan kratos/kratein. Secara etimologi demos diartikan sebagai rakyat, dan kratos/kratein berarti kekuasaan/berkuasa sehingga dapat diartikan bahwa demokrasi adalah pemerintahan rakyat. Demokrasi diidentikan dengan istilah kedaulatan rakyat. Demokrasi atau paham kerakyatan kemudian diasumsikan sama dengan pelaksanaan kedaulatan rakyat yang dalam perkembangannya harus berjalan beriringan dan tidak dapat dipisahkan dengan kedaulatan hukum (nomokrasi) dikarenakan hukum yang mengatur dan membatasi kekuasaan negara atau pemerintah, maka diartikan sebagai produk dari pemerintah. Hukum dibuat atas dasar kekuasaan atau kedaulatan rakyat $^{2}$.

Dewan Perwakilan Rakyat (selanjutnya: DPR) adalah salah satu lembaga negara dalam sistem ketatanegaraan Republik Indonesia yang merupakan lembaga perwakilan rakyat yang memegang kekuasaan membentuk Undang-Undang. DPR terdiri atas anggota partai politik peserta pemilihan umum, yang dipilih berdasarkan hasil pemilihan umum. Anggota DPR berjumlah 560 orang yang masing-masing memiliki masa jabatan 5 tahun, dan berakhir bersamaan dengan pengucapan sumpah/janji bagi anggota DPR yang baru³ .

Karena pada prinsipnya didalam suatu Negara termasuk di Indonesia terdapat tiga jenis kekuasaan, yakni kekuasaan eksekutif, kekuasaan legislatif, dan kekuasan yudisial, yang mana ketiganya saling mengimbang dan mengawasi (check and balances) maka DPR selaku pemegang kekuasaan legislatif (pembentuk Undang-Undang) haruslah bertindak sesuai dengan batasan dan wewenangnya, serta sesuai dengan tujuan kedaulatan rakyat yang telah mengamanatkan suaranya diparlemen melalui DPR. Disamping itu, selain kinerjanya yang dituntut harus sesuai dengan kehendak rakyat, anggota DPR yang juga merupakan anggota partai politik, sikap tindaknya

\footnotetext{
${ }^{1}$ Indonesia, R. (2002). Undang-Undang Dasar Negara Republik Indonesia Tahun 1945. Sekretariat Jenderal MPR RI.

${ }^{2}$ Wibowo, A. S. PENGARUH CITIZEN JOURNALISM TERHADAP DEMOKRATISASI INDONESIA.

${ }^{3}$ Putra, P. S., \& SH, M. (2016). Kewenangan Mahkamah Kehormatan Dewan Terhadap Dugaan Pelanggaran Kode Etik Anggota

Dewan Perwakilan Rakyat Republik Indonesia. Jurnal Ilmiah Hukum DE JURE: Kajian Ilmiah Hukum, 1(1), 93-120.
} 
tidaklah serta merta terbebas dari pengawasan partai politik yang telah mengusungnya sehingga bisa duduk dikursi parlemen. Dengan kata lain, setiap kebijakan yang diambil oleh anggota DPR harus pula sesuai dengan kepentingan dan visi misi partainya masing-masing, jika tidak maka berdasarkan Pasal 12 Undang-Undang Nomor 2 Tahun 2011 tentang Partai Politik, maka partai politik berhak mengusulkan pergantian antar waktu (Recall) kepada anggotanya apabila sikap tindak dan keputusannya diparlemen tidak sesuai dengan kehendak partai politik. Recall dipahami secara umum sebagai penarikan kembali anggota DPR untuk diberhentikan dan digantikan dengan anggota yang lain sebelum berakhir masa jabatan anggota DPR yang ditarik tersebut. Recall sebenarnya tidak saja dapat dilakukan oleh partai politik, tetapi bisa juga oleh Badan Kehormatan DPR dalam hal pelanggaran kode etik DPR.

Rasyid (2004) mengemukakan bahwa pemberhentian Antar Waktu atau yang biasa disebut Recall adalah hak suatu partai politik untuk menarik kembali anggota parlemen yang terpilih melalui daftar calon yang diajukannya. Dalam hal ini makna dari kedaulatan rakyat menjadi semu karena seolah-olah ada Coup dari pimpinan partai yang merebut hak rakyat untuk melakukan Recall menjadi hak partai. Sementara Hatta (2007) menyatakan bahwa hak Recall partai politik yang tidak dapat diganggu gugat itu hanya dikenal di negara-negara komunis, dengan pandangan bahwa partai adalah segala-galanya dan seolah-olah sebagai pihak yang berdaulat. Setelah rakyat memilih orang tersebut sebagai wakil mereka di parlemen, maka partai politik tidak sepatutnya bertindak sewenang-wenang me-Recall wakil rakyat tersebut. Oleh karena itu, dalam konteks ini banyak pemahaman masyarakat yang menyimpulkan bahwa keberadaan hak Recall partai politik mampu menggeser kedaulatan rakyat pada wakilnya di DPR/DPRD.

Selain persoalan yang muncul di atas, hak Recall partai politik juga dapat memicu persoalan di internal partai itu sendiri yang merupakan suatu bentuk konflik kepentingan (conflic of interest). Konflik kepentingan dapat muncul diantara anggota dalam satu partai politik maupun konflik kepentingan antar partai politik. Hal inilah yang akan dikaji lebih jauh dalam tulisan ini untuk melihat bagaimana implikasi hak Recall partai poitikl terhadap konflik internal partai baik secara teoritis maupun yuridisnya. Seperti halnya dalam kasus Recall yang dilakukan oleh Dewan Pimpinan Cabang (DPC) Partai Hanura Kabupaten Lombok Utara (KLU) terhadap saudara Arif Usman, S.Sos, salah satu anggota atau kader partai Hanura yang duduk sebagai anggota DPRD Kab. Lombok Utara priode 2014-2019. Secara sederhana proses recall saudara Arif Usman ini dipicu oleh berbagai gejolak internal partai seperti munculnya ketidaksesuaian antara anggota yang bersangkutan dengan pengurus partai. Proses recall terhadap saudara Arif Usman pula mengakibatkan lambannya berbagai proses kebijakan di internal partai, sehingga peneliti sendiri dapat melihat secara sederhana bahwa recall disebabkan oleh konflik internal partai dan berakibat 
pula pada konflik personal dalam kelembagaan partai. Oleh karena kondisi di atas tersebut, penulis tertarik mengakaji lebih mendalam terkait kasus recall yang menimpa salah satu anggota DPRD Kabupaten Lombok Utara masa bakti 2015-2020, yang di usung oleh Partia Hati Nurani Rakyat (HANURA) DPC Kabupaten Lombok Utara.

\section{METODE PENELITIAN}

Penelitian ini menggunakan Metode Penelitian Kualitatif. Dengan teknik pengumpulan data berupa wawancara, dokumentasi, dan tinajuan pustaka. Informan dalam penelitian ini ditentukan dengan menggunakan teknik purposive, yang artinya informan di tentukan dengan pertimbangan tujuan tertentu. Adapun informan dalam penelitian ini adalah pihak yang berkaitan dengan proses terjadinya keputusan recall di dalam tubuh internal DPC Partai Hanura Lombok Utara, yaitu Ketua DPC Partai Hanura Lombok Utara, Sekretaris DPC Partai Hanura Lombok Utara, Anggota DPRD Fraksi Hanura Lombok Utara, dan Anggota DPRD yang di recall. Analisis data dengan menggunakan Teknik dari Miles dan Huberman (dalam Sugiyono, 2015) yaitu mulai pengumpulan data di lapangan, reduksi data, penyajian data dan penarikan kesimpulan.

\section{HASIL DAN PEMBAHASAN}

Untuk lebih memudahkan peneliti dalam mengkaji secara mendalam terkait dengan pola pengelolaan konflik, dampak terhadap konflik kepentingan, serta pola manajemen konflik yang digunakan oleh DPC Partai Hanura KLU dalam menyelsaikan problem kepartaian yang terjadi Pra maupun Pasca dilakukannya recall Partai Politik, dalam hal ini peneliti menggunakan pendekatan pola yang disebut dengan pola dimensi Pelembagaan Partai yang terbagi dalam empat pendekatan, yaitu pendekatan Systemness, pendekatan Value Infusion, pendekatan Decisional Autonomy, dan pendekatan Reification.

\section{Pendekatan Value infusion}

Pendekatan value infusion menekankan tiga hal dalam melihat secara kelembagan terkait problem yang terjadi di tubuh internal partai Hanura secara kelembagaan, pertama, identitas partai tercermin dalam Anggaran dasar dan anggaran rumah tangga (AD/ART) Partai hanura yang menerangkan secara rinci terkait kelembagaan Parati Hanura. AD/ART Partai Hanura merupakan cita dan jelmaan dari system parati secara umum, sehingga ketika ada satu masalah yang terjadi dalam tubuh internal partai Hanura, seperti Paergantian antar waktu (recall) yang terjadi pada anggota DPRD Partai Hanura Lombok Utara, hal tersebut tidak bisa diputuskan secara personal atau menurut selera pimpinan partai, namun setiap penyelesaian masalah tersebut akan kembali pada aturan yang mengikat seluruh anggota partai yaitu AD/ART. Dengan demikian proses 
pergantian antarwaktu (recall) yang terjadi pada salah satu anggota DPRD Partai Hanura Lombok utara diselesaikan melaui aturan Partai Politik yang tertuang dalam AD/ART. Kedua, ideologi, Asas, Ciri, Nilai dasar perjuangan dan doktrin. Pada pasal 10 AD/ART Partai Hanura menjelaskan tentang Asas Partai Hanura adalah berasaskan Pancasila di Pasal 11 menjelaskan ciri partai yang bersifat nasionalis religius berwawasan nusantara, terbuka bagi seluruh warga negara Republik Indonesia, tanpa membedakan suku, agama, rasa, golongan, status sosial dan gender, ketiga, nilai dasar perjuangan menjelaskan tentang ketakwaan, kemandirian, kebersamaa, kerakyataan dan kesederhanan dalam gerak langkah senantiasa mendasarkan pada nilai etika dan moralitas atas dasar ketuhananan yang Maha Esa. Keempat, dalam doktrinya Partai Hanura, keastuan pemikiran dan paham menyangkut pengahyatan serta serta pelaksanaan Hati Nurani secara nyata dalam perjuangan Partai Hanura merupakan pedoman, pegangan dan bimbingan dalam melaksanakan segala kegiatan dan usaha dalam bidang ideologi, politik, hukum, ekonomi, sosial dan budaya berdasarkan 5 (lima). Kelima, ciri dan nilai dasar perjuangan partai Hanura didasarkan pada paham nasionalis yang digabungakn dengan paham religius, sehingga secara eksplisit menunjukan bahwa partai Hanura secara kelembagaan merupakan gabungan dari dari dua prinsip utama yaitu Nasionalis dan religius. Sehingga dalam penyelesian konflik internal partai, Partai Hanura menempatkan segala sesuatunya dalam kerangka kelembagaan dan penyelesaian masalahnya diselesaikan secara kelembagaan berdasarkan aturan atau norma yang mengikat seluruh anggota Partai.

\section{Pendekatan Systemness}

Dalam pendekatan Systemness ini, beberapa hal penting yang akan dikaji adalah bagaimana suatu konflik itu muncul di internal partai, terutama dalam penelitian ini adalah bagaimana proses hak recall dilakukan oleh DPC Partai Hanura KLU, serta bagaimana dampak yang ditimbulkannya. Pada AD/ART Partai Hanura Bab XIV menyebutkan beberapa poin tetntang penyelesaian konflik atau perselisihan antara partai partai politik dan anggota partai, pertama, setiap perselihan yang terjadi diselesaikan secara dan menurut Anggaran Dasar, Anggaran Rumah Tangga, Peraturan dan Keputusan lainnya. Kedua, Ketentuan lebih lanjut tentang tata cara penyelesaian persilisihan diatur dalam Peraturan Organisasi. Sehingga muatan materi dalam Pasal tersebut menjadi acuan oleh DPC Partai Hanura Kabupaten Lombok utara dalam mengambil setiap kebijakan yang bersifat alternative dalam menyelesaikan konflik internal kelembagaan partai.

Hak Penggantian Antar Waktu (PAW) atau Recall didefinisikan oleh sejumlah ahli, salah satunya oleh Mh. Isnaeni (Ria Farida, 2013) mengatakan: Hak Penggantian Antar Waktu (PAW) pada umumnya merupakan suatu 'pedang Democles' bagi tiap-tiap anggota DPR. Dengan adanya 
hak Recall maka anggota DPR akan lebih banyak menunggu petunjuk dan pedoman pimpinan fraksinya dari pada ber-oto-aktivitas. Melakukan oto-aktivitas yang tinggi tanpa restu pimpinan fraksi kemungkinan besar melakukan kesalahan fatal yang dapat berakibat Recalling. Karena itu untuk keamanan keanggotaannya lebih baik menunggu apa yang diinstruksikan oleh pimpinan fraksinya. Maka tentu amanat controlling ini senantiasa harus mampu dilaksanakan dengan penuh bijak oleh seluruh parpol yang memiliki anggota yang duduk di parlemen Indonesia, supaya jangan disalahgunakan yang kemudian dapat menjadi suatu tindakan abuse of power dari parpol tertentu untuk menekan anggotanya yang kondisi ini sangat bertentangan dengan konsep kedaulatan rakyat.

Sesuai hasil wawancara yan dilakukan oleh peneliti dengan Ketua DPC Partai Hanura Kabupaten Lombok Utara, bahwa Pemberhentian antar waktu (recall) terhadap salah satu anggotanya sudah melalui mekanisme yang diatur oleh UU MD3 juga berpedoman terdapat atauran internal Partai (AD/ART). Memang pada dasarnya pergantian antar waktu (recall) pada dasarnya diatur dala UU No.17 tahun 2014 tentang MD3 padapasal 239 menjelskan bahwa pergantian antar waktu bisa dilakukan bila (1). Anggota parlemen meninggal dunia (2). Mengundurkan diri (3) atau diberhentikan. Bunyi pasal yang sama terdapat pada Pasal 405 tentang pergantian antar waktu bagi anggota DPRD Kabupaten/kota.

Jadi, sebenarnya menurut peneliti pengaturan dalam pasal di atas merupakan kelanjutan dari pengaturan dalam undang-undang MD3 yang mengatur tentang mekanisme pemberhentian anggota di lembaga perwakilan/DPR, dimana secara eksplisit dalam undang-undang di atas memberi mandat kepada partai politik untuk dapat memberhentikan anggotanya secara sah berdasarkan ketentuan dalam AD/ART partai, yang selanjutnya nanti akan berdampak secara otomatis pada pemberhentian status keanggotaan seseorang dalam lembaga DPR. Begitupun pengaturan dalam yang di atur dalam AD/ART Partai Hanura tentang pergantian antar waktu , pada Bab III Pasal 14 AD/ART Partai Hanura Menjelaskan tentang Pemberhentian antar waktu angootanya yang ada di DPR/DPRD, karena meninggal dunia, mengundurkan diri atas permintaan sendiri secara tertulis, menjadi anggota partai lain, melanggar AD/ART partai, tidak memenuhi syarat sebagai anggota dan terlibat dalam tindak pidana yang merugikan nama baik partai. Jadi dalam melaksanakan mekanisme Recall yang dilakukan oleh DPC Partai Hanura KLU terhadap anggotanya di lembaga DPRD KLU telah memiliki dasar hukum dan legalitas formal baik secara aturan Perundang-undangan maupun secara aturan internal organisasi yang dalam hal ini dasar yang paling penting adalah diatur dalam AD/ART Partai.

Jika ditelusuri lebih jauh pengaturan Recall diatur dalam Undang-Undang No. 17 Tahun 2014 tentang MD3 dan Undang-Undang No. 2 Tahun 2011 tetang Partai Politik. Hal ini 
memberikan kewenangan yang luar biasa besar kepada partai politik untuk memberhentikan atau me-Recall anggotanya yang duduk sebagai anggota DPR yang bisa hanya didasarkan atas suka atau tidak suka atau bertentangan dengan kebijakan partai. Bukti sejarah anggota DPR yang diberhentikan oleh pengaturan ini yaitu Lily Wahid dan Effendi Choiri, yang berasal dari Partai Kebangkitan Bangsa. Alasan pemberhentiannya yaitu mereka berbeda pendapat dari kebijakan partai yang menaunginya, dalam keputusan terkait panitia khusus hak angket Bank Century, serta di usulan hak angket mafia pajak.

Sehingga dapat disimpulkan bahwa awal mula adanya hak Recall partai politik adalah dijadikan alat bagi partai politik dalam mengendalikan anggotanya yang ada di parlemen. Hal ini merupakan upaya partai politik dalam mempertahankan kekuasaannya di parlemen. Recall dijadikan pranata untuk membungkam anggota dewan yang kritis dan tidak sesuai dengan kebijakan partai politik. Sehingga pada masa awal reformasi, ketika semangat perubahan untuk mengembalikan kedaulatan ke tangan rakyat, Recall ditiadakan. Dengan begitu, Recall partai politik saat ini tidak selaras dengan semangat demokrasi, karena menempatkan kewenangan partai politik lebih besar daripada rakyat melalui hak Recall partai politik.

Seperti halnya yang dapat dipahami dalam kasus recall terhadap salah satu anggota DPRD KLU, saudara Arif Usman oleh DPC Partai Hanura KLU, seperti yang dijelaskan oleh Ketua DPC Partai Hanura KLU di atas, bahwa sesungguhnya recall terhadap saudara Arif Usman memang merupakan suatu langkah recall atas dasar permintaan secara pribadi oleh Arif Usman atas surat pengunduran dirinya sebagai anggota partai, namun pihak DPC Partai Hanura KLU sendiri sangat memahami bahwa langkah tersebut perlu diambil dalam rangka menjaga marwah partai, terlebih partai hanura merupakan salah satu partai besar, sehingga jika ada anggota yang merasa tidak sejalan dengan ideology dan arah perjuangan partai maka harus diganti atau direcall, inilah yang dipahami sebagai salah satu bentuk controlling terhadap anggota oleh partai.

Sehinngga dalam kasus pemberhentian salah satu anggota Partai Hanura saudara Arif Usman, S.Sos yang sedang menjabat sebagai Anggota DPRD KLU priode 2014-2019 adalah bentuk pemberhentian karena alasan mengundurkan diri, sebagaimana yang diatur dalam Pasal 4 ayat (1) huruf b dalam ART Partai Hanura, oleh karena yang bersangkutan dalam waktu yang bersamaan sedang menjabat sebagai anggota DPRD, maka ketentuan dalam Pasal 4 ayat (2), pemberhentian dari anggota Partai secara otomatis akan memberhentikan yang bersangkutan sebagai anggota DPRD di Kab. Lombok Utara.

Secara rinci dalam pembahasan ini pula peneliti perlu mengatakan penjelasan bahwa pada dasarnya pemberhentian seorang anggota partai (recalling) dapat dilakukan dengan diberhentikan dan berhenti karena mengundurkan diri. Apakah kemudian yang menjadi perbedaan kedua hal 
tersebut. Jika seorang anggota diberhentikan maka tentu terdapat alasan yang dikedepankan oleh pengurus partai misal seorang anggota telah melakukan pelanggaran sebagaimana disebutkan dalam peraturan perundang-undangan dan AD/ART Partai. Sedangkan jika alasan pemberhentian karena yang bersangkutan mengundurkan diri, maka permintaan itu datang dari diri yang bersangkutan baik dalam bentuk lisan maupun tulisan. Jadi dalam kasus pemberhentian Arif Usman oleh DPC Partai hanura KLU sangat jelas berdasarkan pengunduran diri dari yang bersangkutan berdasarkan surat pengunduruan diri yang di sampaikan oleh Arif Usman. Dalam surat pengunduran diri saudara Arif Usman tersebut menjelaskan bahwa yang bersangkutan sudah tidak lagi dapat melaksanakan kebijakan partai secara baik, oleh karena itu keadaan tersebut sangat bertentangan dengan pengaturan tentang disiplin partai, yang telah dijelaskan dalam Pasal 6 AD/ART Partai Hanura bahwa "Anggota Partai harus taat dan patuh terhadap semua ketentuan dan kebijakan partai".

Namun berbeda dengan penjelasan yang bersangkutan yaitu Saudara Arif Usman sebagai pihak yang di recall bahwa terdapat dua alasan menjadi pertimbangannya untuk mengundurkan diri anggota DPRD Kabupaten Lombok Utara sekaligus mengundurkan diri dari Anggota Partai hanura Kabuapaten Lombok Utara, pertama karena memang adanya konflik internal partai yang disebabkan oleh pengangkatan ketua DPC Partai Hanura terpilih, dan kedua oleh akibat dari konflik internal tersebut beliau menduga bahwa dirinya tidak akan dicalonkan lagi oleh Partai karena memang begitu banyak hal yang bertentangan antara anggota dengan pengurus partai. Sangat disayangkan sikap partai yang tidak melihat secara utuh penyelesaian masalah tersebut, jika dilihat dari presentasi suara yang diperoleh anggota DPRD Frakasi Hanura tersebut, bahwa Arif Usman adalah salah satu anggoa partai yang mendapatkan suara terbanyak di Dapilnya. Seperti yang terlihat pada tabel di bawah ini :

Tabel 1

Perolehan Suara Calon Legislatif Kab. Lombok Utara dari Fraksi Partai Hanura Dapil II (Kec. Gangga-Kayangan) periode 2014-2019

\begin{tabular}{|c|c|c|c|}
\hline $\begin{array}{c}\text { NOMOR } \\
\text { URUT } \\
\text { DCT }\end{array}$ & $\begin{array}{c}\text { PARTAI POLITIK/NAMA } \\
\text { CALON }\end{array}$ & $\begin{array}{c}\text { SUARA } \\
\text { SAH }\end{array}$ & $\begin{array}{c}\text { PERINGKAT } \\
\text { SUARA SAH } \\
\text { CALON }\end{array}$ \\
\hline $\mathbf{1}$ & $\mathbf{2}$ & $\mathbf{3}$ & $\mathbf{4}$ \\
\hline \multicolumn{2}{|c|}{ PARTAI HATI NURANI RAKYAT } & 578 & \\
\hline $\mathbf{1 .}$ & AHMAD HUSNAEN, S.Pd & 948 & $\mathbf{2}$ \\
\hline $\mathbf{2 .}$ & JAHARUDIN, S.Sos & 412 & $\mathbf{5}$ \\
\hline
\end{tabular}


Journal of Government and Politics (JGOP) Vol. 2 No. 1 Juli 2020 Hal. 57-72

\begin{tabular}{|c|l|c|c|}
\hline $\mathbf{3 .}$ & HURIAH & 26 & 9 \\
\hline $\mathbf{4 .}$ & SAHDAN & 406 & $\mathbf{6}$ \\
\hline $\mathbf{5 .}$ & BUDI HARTONO & 768 & $\mathbf{3}$ \\
\hline $\mathbf{6 .}$ & YULI FATMA AENI & 28 & 8 \\
\hline $\mathbf{7 .}$ & ARIF USMAN, S.Sos & 1.233 & $\mathbf{1}$ \\
\hline $\mathbf{8 .}$ & MAHIRUNIATUN & 22 & 11 \\
\hline $\mathbf{9 .}$ & RANGGA EKA PUTRA & 23 & 10 \\
\hline $\mathbf{1 0 .}$ & SUDIARSAH & 581 & 4 \\
\hline $\mathbf{1 1 .}$ & SRI WATI & 22 & 7 \\
\hline $\mathbf{1 2 .}$ & PUTRAWADI,SH & 309 & \\
\hline & JUMLAH & 5.356 & 11 \\
\hline
\end{tabular}

Sumber : diolah dari data KPU Kab.Lombok Utara dan DPC Partai Hanura KLU

Tabel di atas menjelaskan tentang peroleh suara Anggota Partai Hanura Dapil 2 Kecamatan Kayangan-Gangga Lombok Utara. Dari 12 calon yang di calonkan partai Hanura Kabupaten Lombok Utara Dapil 2, Arif Usman menjadi anggota yang mempeoleh suara terbanyak dengan perolehan suara 1.233 suara. Dan hal tersebut ketika yang bersangkutan mengundurkan diri dan terjadi pergantian antar waktu (recall), apalagi pengundurn diri yang bersangkutann ditengarai karena adanya konflik kepentingan yang terjadi di tubuh internal Partai Hanura DPC Kabupaten Lombok Barat, hal demikian akan berimbas melekat citra buruk bagi partai dan tentu akan sangat merugikan partai itu sendiri, selain akan menurunkan elektabiltas serta popularitas partai, juga akan dimanfaaatkan oleh partai yang lain untuk dapat mengambil alih basis masa milik Arif Usman. Kerugian lain tentu akan menggiring opini publik di lombok utara, bahwa untuk Pileg periode selanjutnya masyarakat akan menjatuhkan pilihan politiknya tidak lagi di Partai Hanura, namun di partai lain yang sudah meminang saudara Arif usman, dan hal tersebut akan berdampak kurangnya perolehan suara Partai Hanura sekaligus kurangnya Kursi di DPRD Lombok Utara.

\section{Pendeketan Decisional Authonomy}

Dalam pola pendekatan Decisonal Autonomy, untuk melihat kebijakan-kebijakan strategis yang diambil oleh Parpol dalam menyelesaikan konflik-konflik kepentingan yang terjadi pada internal partai guna tetap melanjutkan cita perjuangan dan pengabdian Parpol. Tentu dalam hal ini diharapkan partai politik dapat menjadi wadah yang selalu mencerminkan intelektualitas politik dalam menyelesaikan segala persoalan dan konflik. Di tubuh internal Partai Hanura Lombok utara ada beberapa mekanisme dalam menyelesaikan konflik internal. Langkah-langkah yag ditempuh, Pimpinan selalu melakukan konsolidasi, mediasi, musyawarah-mufakat dengan anggota, pengurus 
partai, kader dan seluruh simpatisan, langkah tersebut diamabil guna untuk mendapat pandangan kepada stakolder partai yang ada untuk mencari jalan terbaik dalam menyelesaikan masalah yang tengah dihadapi partai, sehingga pemecahan masalah yang dilakukan sebisa mungkin tidak merugikan siapapun. Jadi dalam rangka meminimalisir dampak dari adanya pelaksanaan Recall oleh partai, musywarah dan perundingan menjadi jembatan dalam menyelsesaikan yang muncul baik pra dilaksanakan Recall maupun pasca dilaksanakannya Recall terhadap anggota di dalam partai yang bersangkutan.

Sedangkan di kelembagaan DPRD Kabupaten Lombok Utara sendiri, terdapat beberapa mekanisme yang dilakukan oleh DPRD Kabupaten Lombok Utara secara kelembagaan dalam mengatasi stagnasi yang disebabkan oleh pelaksanaan Recall ditengah priode jabatan DPRD, yaitu dengan dibentuknya Badan Musyawarah (BAMUS) yang tugasnya untuk mengatur masa sidang, karena dalam satu tahun DPRD bisa melakukan 3-4 kali termasuk mengatur sidang PAW (recall) anggota Dewan yang digantikan oleh anggota yang lain. Disisi yang lain dengan adanya Pergantian antar waktu (recall) yang terjadi di DPRD akan mengganggu jalannya kebijakan DPRD, hal tersebut dikarenakan, bahwa aggota legislatif baru yang menggantikan anggota PAW membutuhkan waktu yang lama untuk menyesuaikan diri dengan kerja-kerja legisltatif. namun ada beberapa mekanisme yang harus dilakukan agar masalah tersebut tidak membuat segala aktivitas di lembaga DPRD menjadi terhambat yaitu dengan cara mebentuk BAMUS dan memaksimalkan kerjanya Sekwan di DPRD.

Selain mekanisme penyelsaian konflik yang dilakukan dalam bentuk memperkuat system internal partai dan memperkuat posisi di internal lembaga DPRD, DPC Partai Hanura juga meminimalisir munculnya segala persoalan kelembagaan partai dengan memperkuat hubungan dengan aktor di luar kelembagaan partai, yaitu dengan terus berupaya menjaga hubungan baik dengan partai-partai lain, khususnya partai yang memiliki ikatan kepentingan yang sama dengan Partai Hanura dalam struktur kelembagaan DPRD Kabupaten Lombok Utara yaitu terhadap partai yang satu Frkasi dengan Partai hanura yaitu, PKB dan PPP.

\section{Pendekatan Reification}

Dalam pendekatan Reification yang penting dilihat sejauh mana partai politik dapat menerapkan system komunikasi yang baik secara kelembagaan untuk mempertahankan kesetiaan konstituennya, anggota, kader, dan basis masanya. Sistem komukasi yang baik akan meminimalisir terjadinya konflik atau masalah dalam tubuh partai, dengan demikian pimpinan partai harus menjadi teladan sekaligus contoh yang baik untuk seluruh anggotanya, menggunakan komukasi yang baik, menyelesaikan setiap masalah yang terjadi dengan komunkasi yang baik secara kelembagaan maupun secara aturan yang sudah di atur dalam AD/ART partai. Jika 
komunikasi yang baik bisa dijalankan dan ditempuh dengan cara-cara yang baik sesuai prosedur yang ada, tentu kasus seperti recall karena adanya konflik internal disebabkan ada perbedaan pandangan antara pimpina partai dengan anggota tidak akan terjadi.

Dalam Pasal 22 AD/ART Partai Hanura dijelaskan bahwa terdapat beberapa hal tentang kewajiban partai yang dalam hal ini tentu berdampak penting dalam menjaga keutuhan basis politik partai, seperti dijelaskan dalam ayat (7) bahwa salah satu kewajiban partai adalah melakukan pendaftaran dan pendataan anggota, yang nantinya data tersebut digunakan sebagai sumber database keanggotaan partai. Selain itu Partai Hanura juga aktif dalam melakukan pendidikan politik, yang berdasar pada pengaturan dalam Pasal 23 AD/ART, yang menyebutkan bahwa:

Partai Politik melakukan pendidikan politik bagi masyarakat sesuai dengan ruang lingkup tanggung jawabnya dengan memperhatikan keadilan dan kesetaraan gender dengan tujuan antara lain, Meningkatkan kesadaran hak dan kewajiban masyarakat dalam kehidupan bermasyarakat, berbangsa dan bernegara; Meningkatkan partisipasi politik dan inisiatif masyarakat dalam kehidupan bermasyarakat, berbangsa dan bernegara; dan Meningkatkan kemandirian, kedewasaan dan membangun karakter bangsa dalam rangka memelihara persatuan dan kesatuan bangsa. Pendidikan politik sebagaimana dimaksud dalam ayat (1) dilaksanakan untuk membangun etika dan budaya politik sesuai dengan Pancasila.

Selain hal tersebut diatas untuk menjaga kesetian konstituenya, anggota dan juga kader metode komunikasi yang digunakan dengan membentuk alat kelengkapan Partai yang di atur dan termuat dalam Pasal 19 AD/ART Partai Hanura sebgai berikut : Alat kelengkapan partai dibentuk oleh dewan pimpinan/pimpinan partai sesuai tingkatannya berdasarkan peraturan organisasi yang dikeluarkan dewan pimpinan pusat; Wewenang dan kewajiban alat kelengkapan partai adalah melakukan tugas dan fungsi di bidangnya masing-masing dalam rangka mendukung program dan kegiatan partai; Alat kelengkapan partai teridir dari:
a. Badan Pendidikan Dan Latihan (Badiklat);
b. Badan Penelitian Dan Pengembangan (Balitbang);
c. Badan Informasi Dan Strategis (Bainfostra);
d. Devisi Komunikasi Public;
e. Lembaga Bantuan Hukum;
f. Brigade (Barisan Garda Depan) Hanura;
g. Organisasi Sayap (Orsap).

Pembentukan lembaga-lembaga sayap atau alat kelengakapan partai tersebut, tujuannya untuk memperekat komunikasi antara anggota, kader, basis massa dengan masyarakat atau 
konstituen, dengan adaya alat kelengkapan partai seperti itu memberikan sinyal positif untuk distribusi kewenangan, sehingga seluruh anggota memiliki kewenangan sesuai jabatan yang telah di embannya, hal demikian tentu dengan banyaknya simpul-simpul yang ada memberi peluang kepada partai untuk tetap menjalin hubungan yang baik dengan masyarakat sebagai pemilik suara sah dalam menentukan pilihan ketika dilaksanakan Pemilu Presiden, Pemilu Kepala daerah, dan Pemilu Legislatif. Selaian hal di atas terdapat beberapa upaya yang dilakukan oleh Partai Hanura Kabupaten Lombok Utara dalam menjaga kesetiaan kader dan anggota partai, diantaranya: memperbaiki administrasi keanggotaan partai, menjalanakn hak dan kwajiban anggota, menjalankan fungsi pendidikan politik bagi anggota partai, dan membentuk alat kelengkapan partai sebagai komunitas tersendiri bagi para anggota partai dalam berkontribusi bagi pengembangan partai.

\section{PENUTUP}

Konflik kepentingan pasca pergantian antara waktu anggota DPRD Frakasi Hanura Kabupaten Lombok Utara menyebabkan beberapa masalah ditubuh internal partai, implikasi yang pertama yang menyebabkan terjadinya konflik internal dalam Partai Hanura Kabupaten Lombok Utara, terjadi tumpang tindih kewenangan, sehingga adanya ketidak percayaan terhadap pimpinan partai. Kedua pasca Recall terjadi perebutan kursi pengganti di DPRD Kabupaten Lombok Utara untuk jatah Partai Hanura setelah Arif Usman mengundurkan diri, beberapa anggota partai mulai mebuka rahasia partai di publik atas ketidaknyaman terhadap pengurus baru Partai Hanura Kabupaten Lombok Utara, munculnya ketidakpercayaan anggota terhadap pengurus baru, sehingga menyebabkan beberapa anggota dan kader-kader yang militan memilih hengkan dari dari Partai Hanura Lombok Utara, dan berimbas pada menurunya elektabilitas Partai Hanura Lombok Barat pasca Recall, dampak yang lain Partai Hanura kehilangan Basis Masa di daerah Pemilihan Arif Usman, dan terbukti pada Pemilu legislatif 2019 Partai Hanura mengalami kemerosotan suara. Dan tidak mendapat satu kursipun di DPRD Kabupaten Lombok Utara. Kedua, dengan adanya hak Recall yang dimiliki oleh Parta Politik juga berdampak secara kelembagaan terhadap lembaga DPRD Lombok Utara, hal tersebut telihat dari lambannya pelaksanaan kebijakan di DPRD, karena lamanya proses pergantian yang dilakukan oleh Partai pengusul pengganti anggota baru DPRD Kabupaten Lombok Utara. Dampak lain yang disebabkan oleh adanya kebijakan Recall memberikan persepsi di masyarakat, bahwa kedaulatan rakyat tidak lagi di tangan rakyat, namun abergeser menjadi di tangan Partai Politik pengusung anggota Dewan, sehingga ketika terjadi konflik inetrnal yang terjadi antara Anggota DPRD dengan Pimpinan Partai Politik pengusungnya, dengan alasan Aturan, anggota Dewan yang memiliki pandangan yang berbeda, 
Journal of Government and Politics (JGOP) Vol. 2 No. 1 Juli 2020 Hal. 57-72

atau memiliki cara berpikir yang berbeda dengan pimpinan partai politik otomatis nasibnya akan berakhir dengan pemecetan sebagai anggota Partai sekaligus Anggota Legistatif. 
Journal of Government and Politics (JGOP) Vol. 2 No. 1 Juli 2020 Hal. 57-72

\section{DAFTAR PUSTAKA}

Amal, Ichlasul, \&Panggabean, Samsurizal, 2012, "ReformasiSistem Multi-Partai Dan PeningkatanPeran DPR Dalam Proses Legislatif, , Tiara Wacana, Yogyakarta.

Ananda B. Kusuma, 2006, Jurnal Konstitusi Volume 3 Nomor 4 Tentang Recall, (Jakarta:

Asshiddiqie, Jimly, 2006, Partai Politik Dan PemilihanUmum Sebagai Instrumen Demokrasi, JurnalKonstitusi, Volume 3, Nomor 4, Desember, Sekretariat Jendral Dan Kepaniteraan Mahkamah Konstitusi, Jakarta.

Bintan R. Siragih, 1988, Lembaga Perwakilan dan Pemilihan Umum di Indonesia, (Jakarta: Gaya Media Pratama)

Coser, Lewis, 2009, Sosiologi Konflik dan Isu-Isu Konflik Kontemporer, PT.Raja Grafindo Persada, Jakarta

Daud, IrnaIrmalina, 2009, "Rerformasi Dan ArahPerubahanPolitik Indonesia

Fahmi, Khairul, 2010, Prinsip Kedaulatan Rakyat Dalam Penentuan Sistem Pemilihan Umum Anggota Legislatif, JurnalKonstitusi, Volume 7, Nomor 3, Juni, SekretariatJendral Dan Kepaniteraan MahkamahKonstitusi, Jakarta

Indonesia, R. (2002). Undang-Undang Dasar Negara Republik Indonesia Tahun 1945. Sekretariat Jenderal MPR RI.

Malicia Evendia, 2012, Implikasi Hak Recall Partai Politik Terhadap Sistem Kedaulatan Rakyat. Jurnal Fiat Justitia Jurnal Ilmu Hukum Volume 6 No.3 Sept.-Desember 2012 .

Nurlatipah Nasir, 2016, Electoral Volatility Dalam Perspektif Kelembagaan Partai Politik Di Indonesia : Sebuah Analisis Hubungan Partai Politik Dengan Konstituen, JurnalPolitikProfetik, Volume 04, Nomor 1, Tahun 2016.

Rida Farida, 2013, Mekanisme Penggantian Antar Waktu (Paw) Anggota DPR Dan Implikasinya Dalam Konsep Perwakilan Rakyat, (jurnalJurnal Cita Hukum. Vol. I No. 2 Desember 2013).

Stevanus Evan Setio, Hak Recall Partai Politik Terhadap Keanggotaan DPR Dalam Sistem Ketatanegaraan Indonesia, (Tesis Pada Program Pascasarjana Universitas Udayana, Denpasar, 2013).

AnggaranDasar/AnggaranRumahTangga (AD/ART) Partai Hati Nurani Rakyat (HANURA), yang disahkan pada tanggal 21 Desember 2016, oleh Dewan Pimpinan Pusat (DPP) Partai Hanura, di Jakarta. 
Journal of Government and Politics (JGOP) Vol. 2 No. 1 Juli 2020 Hal. 57-72

Undang-UndangDasar Negara Republik Indonesia Tahun 1945.

Undang-Undang Nomor 4 Tahun 1999 tentang Susunan dan Kedudukan Majelis Permusyawaratan Rakyat, Dewan Perwakilan Rakyat, dan Dewan Perwakilan Rakyat Daerah. Undang-Undang Nomor 2 Tahun 2008 Tentang Partai Politik yang telah di ubah dengan Undang-Undang Nomor 2 Tahun 2011 tentang Perubahan AtasUndang-Undang Nomor 2 Tahun 2008 Tentang Partai Politik.

Undang-Undang Nomor 27 Tahun 2009 Tentang Majelis Permusyawaratan Rakyat, Dewan Perwakilan Rakyat, Dewan Perwakilan Daerah, dan Dewan Perwakilan Rakyat Daerah Undang-UndangNomor 17 Tahun 2014 tentang MPR, DPR, DPD, dan DPRD.

Peraturan Pemerintah No. 12 Tahun 2018 tentang Pedoman Penyusunan Tata Tertib Dewan Perwakilan Rakyat Daerah Provinsi, Kabupaten, Dan Kota.

Peraturan Komisi Pemilihan Umum (PKPU) No. 6 Tahun 2017 tentang Pergantian Antar Waktu (PAW) Anggota DPR, DPD, DPRD Provinsi, dan DPRD Kabupaten/Kota.

PutusanNomor 008/PUU-IV/ 2006, bertanggal 28 September 2006),

PutusanNomor 22-24/PUU-VI/2008

Putra, P. S., \& SH, M. (2016). Kewenangan Mahkamah Kehormatan Dewan Terhadap Dugaan Pelanggaran Kode Etik Anggota Dewan Perwakilan Rakyat Republik Indonesia. Jurnal Ilmiah Hukum DE JURE: Kajian Ilmiah Hukum, 1(1), 93-120.

Wibowo, A. S. PENGARUH CITIZEN JOURNALISM TERHADAP DEMOKRATISASI INDONESIA. 